\title{
JEROME, ANTIOCH, AND THE DESERT: A NOTE ON CHRONOLOGY
}

\section{Author(s): J. H. D. Scourfield}

Source: The Journal of Theological Studies, NEW SERIES, Vol. 37, No. 1 (APRIL 1986), pp. $117-121$

Published by: Oxford University Press

Stable URL: https://www.jstor.org/stable/23962984

Accessed: 07-05-2020 11:16 UTC

JSTOR is a not-for-profit service that helps scholars, researchers, and students discover, use, and build upon a wide range of content in a trusted digital archive. We use information technology and tools to increase productivity and facilitate new forms of scholarship. For more information about JSTOR, please contact support@jstor.org.

Your use of the JSTOR archive indicates your acceptance of the Terms \& Conditions of Use, available at https://about.jstor.org/terms

Oxford University Press is collaborating with JSTOR to digitize, preserve and extend access to The Journal of Theological Studies 


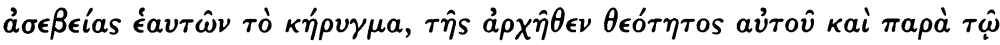

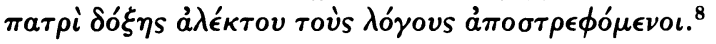

If gent. and inc. are a catechetical work, as Petterson says, ${ }^{9}$ they offer a catechesis tailor-made for a community in which Arian instruction might also be available. Athanasius may be trying to replace earlier catechetical treatises which were not proof against Arian manipulation with new ones which were. Then not 'the scarcity of books at the time'10 but the lack of books containing a prophylactic against Arian teaching would have led to the writing of our two treatises, and the much-discussed reference in gent. I to not having his teachers' books at hand would be merely a graceful excuse for his writing the books which he was determined to write anyway.

Michael Slusser

\section{JEROME, ANTIOCH, AND THE DESERT: A NOTE ON CHRONOLOGY}

When did Jerome leave Antioch for the desert of Chalcis? F. Cavallera, writing more than sixty years ago, put the departure in the second half of $375 ;{ }^{1}$ according to the latest biographer, J. N. D. Kelly, it fell in late summer or early autumn 374 , or perhaps early in the following year. ${ }^{2}$ In this article I wish to argue against Kelly's view, ${ }^{3}$ and in so doing to discuss the evidence more fully than I believe has been done hitherto.

Kelly demonstrates convincingly that it must have been towards the end of 372 that Jerome left Aquileia for the East, and that he probably arrived at Antioch in the latter half of the following year. ${ }^{4}$ There he settled at the house of his friend Evagrius, who had left Italy at about the same time. ${ }^{5}$

It was during this stay at Antioch that Jerome wrote the earliest of his surviving works, Letter I. A mannered and rhetorical piece, this is addressed to a second friend, Innocentius, who was also a guest at Evagrius' house. It can safely be assigned to this period, because Jerome was still at Antioch when Innocentius died, ${ }^{6}$ and reference

8 Alexander of Alexandria, ep.Alex. 4, ed. H. G. Opitz, Athanasius Werke, iii (Berlin: W. de Gruyter, 1934-5), 20, 7-I I; see also ep. Alex. 37.

9 Art. cit. 1038.

10 Ibid. 1031.

1 F. Cavallera, Saint Yérôme: sa vie et son œuvre (Spicilegium sacrum Lovaniense I-2; 2 vols., Louvain, 1922), 2. I4-1 5 .

2 J. N. D. Kelly, Ferome: his Life, Writings, and Controversies (London, 1975 ), 46.

3 This is in no way to imply criticism of Kelly's book as a whole, which I have found an indispensable guide to the man and his work.
4 Kelly, 36-7.
5 Cf. Kelly, 35, 38.
${ }^{6}$ Cf. Jer. Ep. 3. 3. 1-2. 
is made in the letter to the death in 374 of Auxentius, the Arian Bishop of Milan, whose immediate successor in the episcopal seat was Ambrose. The relevant passage requires some discussion:

quis enim valeat digno canere praeconio Auxentium Mediolani incubantem huius [sc. Evagrii] excubiis sepultum paene ante quam mortuum ...?

(Jer. Ep. 1. 1 5. 2)

According to G. Grützmacher, mortuum should be taken to refer not to Auxentius' death but to his earlier condemnation for heresy by a Roman synod under Damasus; in other words, when Jerome wrote the passage Auxentius was only ecclesiastically 'dead'. ' But this is heterodox to the point of implausibility, and admits of an easy explanation. Grützmacher nowhere challenges the accepted view that Auxentius died in 374, and as he also believed, on no good grounds, that the letter must have been written not later than 373 , he had no choice but to dispose of the natural meaning of mortuum. The obvious interpretation is that when Jerome wrote the letter Auxentius was already dead. ${ }^{8}$

That it was in 374 that Auxentius died seems to be clear. Paulinus, Ambrose's secretary and biographer, indicates that no great length of time elapsed between Auxentius' death and Ambrose's accession-probably just a few weeks. ${ }^{9}$ The date of Ambrose's consecration is well established as 7 December 374 . The year is given by Jerome's Chronicle, the reading having been firmly fixed, after some dispute, by $\mathrm{O}$. Faller. ${ }^{10}$ The date and month are enshrined in tradition; see, for instance, the Martyro-

7 G. Grützmacher, Hieronymus: eine biographische Studie (3 vols., Leipzig and Berlin, 1901-8), I. 53-4. Grützmacher put the synod in 369, though the date has been much disputed. The fullest discussion is that of $\mathrm{F}$. Savio, Gli antichi vescovi d'Italia dalle origini al 1300 , descritti per regioni. La Lombardia, I: Milano (Firenze, I913), $839 \mathrm{ff}$., who argues for 372.

${ }_{8}$ As both Cavallera, 2. 13 , and Kelly, 39 n. 19, accept. Cavallera is, however, wrong to suppose that the passage implies that Evagrius did not leave for the East until after Auxentius' death.

sepultum deserves a brief comment. Jerome must be alluding to attempts on Evagrius' part to put down Auxentius, who had maintained his position in Milan for many years despite repeated condemnation for heresy and attacks by orthodox Christians such as Hilary of Poitiers, Athanasius of Alexandria, and Philaster of Brescia. About these attempts we know nothing more; but they are entirely in keeping with a man who, like Hilary and the rest, was staunchly Nicene.

9 Paul. Med. vita Ambr. 6-9.

10 'La data della consecrazione vescovile di sant 'Ambrogio', Ambrosiana: scritti di storia, archeologia ed arte pubblicati nel XVI centenario della nascità di sant' Ambrogio (Milano, 1942), 97-112. H. von Campenhausen, Ambrosius von Mailand als Kirchenpolitiker (Berlin, 1929), 90-2, and J.-R. Palanque, Saint Ambroise et l'Empire Romain (Paris, 1933), 484-7, had argued that the true reading was 373 . 
logium Hieronymianum, ${ }^{11}$ which assigns Ambrose's baptism to 30 November, thus establishing 7 December as the date of the consecration, ${ }^{12}$ or the Calendar of Beroldus of Milan. ${ }^{13}$ The fact that in 3747 December fell on a Sunday, the usual day for consecration ceremonies, ${ }^{14}$ substantiates the case. Auxentius, then, is likely to have died around October 374. Allowing some time for news of Auxentius' death to have reached Jerome at Antioch, Innocentius can hardly have died before early 375 .

The death of Innocentius is reported by Jerome in his third Letter, in which he gives Rufinus an account of his journey from Aquileia to the East:

cum me Thracia, Pontus atque Bithynia totumque Galatiae vel Cappadociae iter et fervido Cilicum terra fregisset aestu, Syria mihi velut fidissimus naufrago portus occurrit. ubi ego quicquid morborum esse poterat expertus e duobus oculis unum perdidi; Innocentium enim partem animae meae, repentinus febrium ardor abstraxit.

(Jer. Ep. 3. 3. I)

If this passage gives the impression that Innocentius died quite soon, perhaps only a matter of months, after Jerome's arrival at Antioch, it is misleading. From what has been said above, more than a year must have intervened between the two events. In any case, quicquid morborum esse poterat expertus may easily conceal an interval of that kind of length; and Jerome is, after all, giving Rufinus a very brief outline of what has happened to him since their parting at Aquileia, and the chronology may be heavily compressed.

This letter certainly represents the first correspondence between the two since Jerome left his friend behind in Italy in 372 . But Rufinus had not remained there for long. ${ }^{15} \mathrm{He}$ soon went to Alexandria, where he observed the persecution which followed the death of Bishop Athanasius on 2 May $373 \cdot{ }^{16} \mathrm{~A}$ report that he was at Nitria, the centre of Egyptian monasticism, was subsequently conveyed to Jerome by their mutual friend Heliodorus, but it came at second hand and Jerome did not give it full credence. ${ }^{17}$ It was only when the report had been confirmed by a series of travellers

11 Acta sanctorum, Nov., 2. 2 (eds. H. Delehaye and H. Quentin, Bruxellis, 1931), 628-9.

12 Paul. Med. vita Ambr. 9 states that Ambrose was consecrated on the eighth day after his baptism, i.e. a week later.

${ }^{13}$ Beroldus sive ecclesiae Ambrosianae Mediolanensis kalendarium et ordines saec. $X I I$, ed. M. Magistretti (Mediolani, 1894).

${ }^{14}$ Cf. T. Michels, Beiträge des Bischofsweihetages im christlichen Altertum und im Mittelalter (Liturgiegeschichtliche Forschungen Io; Münster im Westf., 1927).

15 The implication of Ep. 3. 3. I 'postquam me a tuo latere subitus turbo convolvit' is clearly that Jerome, not Rufinus, left Aquileia first.

${ }^{16}$ Cf. Kelly, 36.

17 Cf. Jer. Ep. 3. 2. 1. 
that he accepted that it was true, and, overjoyed at the news, wrote to Rufinus, saying that only illness had prevented him from going to Nitria to join him:

Rufinum enim Nitriae esse et ad beatum perrexisse Macarium crebra conmeantium multitudo referebat. hic vero tota credulitatis frena laxavi et tunc vere aegrotum esse me dolui. et nisi me adtenuatae corporis vires quadam conpede praepedissent, nec mediae fervor aestatis nec navigantibus semper incertum mare pia festinatione gradienti valuisset obsistere.

(Jer. Ep. 3. 2. 2-3)

mediae fervor aestatis has generally been taken to set the date of the piece in summer. ${ }^{18}$ But some caution must be exercised. It refers, strictly, not to the time of writing, but to the time when Jerome became convinced of the truth of the report. It could be maintained that some time elapsed between these events. If Jerome was too ill to travel, he was perhaps also too ill to write. He certainly writes as if looking back in time; note particularly the pluperfects praepedissent, valuisset. It cannot be argued that Jerome changed the tenses of the verbs in this passage later, immediately prior to sending it. While it must be true that, having written the letter, he held on to it for a time, awaiting a convenient courier - it was eventually dispatched, with a covering letter to Florentinus, ${ }^{19}$ when Jerome had heard a rumour that Rufinus had gone from Nitria to Jerusalem ${ }^{20}$-it cannot be supposed that he made alterations when the letter still refers to Rufinus as being at Nitria:

audio te Aegypti secreta penetrare, monachorum invisere choros et caelestem in terris circuire familiam.

(Jer. Ep. 3. I. I)

Let us suppose, then, that Jerome's conviction that Rufinus was at Nitria took shape not in the summer of 375 but in the middle of the previous year. If Rufinus had gone to Nitria soon after the Alexandrian troubles in mid-373, there would have been a year or so-plenty of time-for the crebra conmeantium multitudo to have brought news of him to Antioch. Jerome then, from illness or other reasons, waited until the following year, until after the death of Innocentius, before writing to Rufinus.

But is this the most plausible interpretation of the evidence? Even if mediae fervor aestatis refers to the late summer of 374, August or September, there is still a gap of several months before Jerome

18 Cf., e.g., Cavallera, 2. 14, J. Labourt (ed.), Saint férôme: Lettres (8 vols., Paris, 1949-63), I. I I; also Kelly, 45, who puts the piece in the summer not of 375 but of 374, no doubt forgetting that Letter I, to Innocentius, postdates Auxentius' death around October of that year (see pp. I 8 8-19 above, and n. 8).

19 Letter 4. There is no reason to suppose that the letter to Rufinus to which Jerome refers in Letter 4 (4. 2. I) is anything other than Letter 3.

20 Cf. Jer. Ep. 4. 2. I. 
writes Letter 3 . Is it likely that he would have delayed so long before writing to his close friend, whom he had not seen or heard from since 372 , once he knew for sure where he was? He was weakened by illness when confirmation of the news about Rufinus was brought by the travellers; but he was still weak at the time of writing. ${ }^{21}$ Nor are the pluperfects a serious difficulty. Jerome is looking back, but not necessarily over a long period. They may be specifically epistolary pluperfects, anticipating the moment of reading by the addressee. Rufinus may have lingered at Alexandria, or stayed elsewhere in Egypt, for a considerable time before going to Nitria. How long it took for confirmation of Heliodorus' report by crebra conmeantium multitudo there is no way of telling.

It seems much more likely that mediae fervor aestatis refers to the summer of 375 , and that Letter 3 belongs not to the early part of that year but to the same period. Some time will have passed before the letter was eventually sent. Jerome's journey to the desert will not, then, have taken place before late $375 .^{22}$

The argument I have put forward is less than watertight. But the suggested dating has probability on its side. To accept the alternative view - that Jerome left Antioch in late 374 or early 375-requires one to ignore the problems thus raised over mediae fervor aestatis, or to assume an earlier date than Paulinus suggests for the death of Auxentius (and, consequently, for the death of Innocentius and the writing of Letter 3), or to reject the traditional dating for Ambrose's consecration, or to accept the discredited belief of Grützmacher about the meaning of mortuum in Letter I. To do any of these things would, I submit, be tendentious, or at the very least strain the evidence unnecessarily. ${ }^{23}$

J. H. D. ScourfiEld

\section{THE DESTRUCTION OF IDOLS-SINFUL OR MERITORIOUS?}

DURING the first four and a half centuries of the life of the Christian church there were considerable changes in Christian attitudes towards the destruction of pagan idols and shrines. This

21 Cf. Ep. 3. I. 2.

22 Jerome had gone to the desert by the time he wrote Letter 5 , also to Florentinus; cf. 5. I. I. (He was still with Evagrius when he wrote Letter 4 ; cf. 4. 2. 2.) This piece presupposes that Florentinus has received Letter 4 and replied to Jerome, saying that the rumour that Rufinus had gone to Jerusalem was untrue; 5. 2. 1. Communications between Antioch (with which, after his departure, Jerome kept in close contact) and Jerusalem will have been good, and there is no reason to assume a long delay between Letters 4 and 5 .

${ }^{23}$ I should like to thank Professor F. R. D. Goodyear, Dr J. F. Matthews, and Sir Ronald Syme for commenting on earlier drafts of this paper. 